\title{
PENEGAKAN SANKSI TERHADAP APARATUR SIPIL NEGARA YANG MELAKUKAN PELANGGARAN DISIPLIN DI LINGKUNGAN PEMERINTAH KOTA DENPASAR
}

\author{
Ni Luh Sandiani, I Gusti Bagus Suryawan, Ida Ayu Putu Widiati \\ Fakultas Hukum Universitas Warmadewa, Denpasar - Bali, Indonesia
}

\begin{abstract}
Abstrak
Permasalahan yang dihadapi oleh birokrasi Indonesia salah satunya yakni pelanggaran disiplin yang dilakukan oleh ASN. Maka dari itu, dibentuklah UU No. 5 /2014 tentang ASN dan PP No. 53 / 2010 tentang Disiplin PNS. Berdasarkan latar belakang ini, penelitian ini dilakukan dengan tujuan menguraikan bagaimana pengaturan disiplin ASN pada Pemerintah Kota Denpasar berdasarkan UU No.5 / 2014 tentang ASN dan PP No. 53 /2010 tentang Disiplin PNS dan bagaimana penegakan sanksi hukum bagi ASN yang melakukan pelanggaran disiplin di lingkungan Pemerintah Kota Denpasar. Penelitian ini didesain dengan menggunakan pendekatan empiris. Penelitian ini dilakukan langsung di BKPSDM Kota Denpasar dengan melakukan wawancara terhadap Kasubid Disiplin dan Penghargaan BKPSDM Kota Denpasar. Hasil penelitian ini menunjukkan bahwa pengaturan kedisiplinan ASN di BKPSDM sudah diatur secara jelas pada UU ASN dan PP No. 53 /2010 tentang Disiplin PNS, dan penegakan sanksi hukum di BKPSDM bagi ASN yang melakukan pelanggaran disiplin juga berpedoman pada UU No. 5/2014 tentang ASN dan PP No 53/2010 tentang Disiplin PNS. Peraturan perundangundangan tersebut sudah memiliki aturan yang jelas. Penyebab masih terjadinya pelanggaran disiplin yang dilakukan oleh ASN yaitu ASN tidak memahami aturan, pimpinan tidak bersikap tegas, kurangnya pengawasan melekat (WASKAT), dan kurang memberikan apresiasi dan pujian terhadap bawahan.
\end{abstract}

Kata Kunci: Aparatur Sipil Negara, Pelanggaran Disiplin, Sanksi

\begin{abstract}
One of the problems faced by the Indonesian bureaucracy is the violation of discipline by Civil Servants. Therefore, Law No. 5 of 2014 concerning Civil Servants and PP No. 53/2010 concerning Civil Servant Discipline. Based on this background, this research was conducted with the aim of outlining how the discipline of Civil Servants in Denpasar City Government based on Law No.5 / 2014 concerning ASN and PP No. 53/2010 concerning Discipline of Civil Servants and how to enforce legal sanctions for Civil Servants who commit disciplinary violations within the Denpasar City Government. This research was designed using an empirical approach. This research was conducted directly at the Denpasar City BKPSDM by conducting interviews with the Kasubid Discipline and the Denpasar City BKPSDM Award. The results of this study indicated that the regulation of Civil Servant discipline in the BKPSDM is clearly regulated in the Civil Servant Law and PP No. 53/2010 concerning Discipline of Civil Servants, and enforcement of legal sanctions at the BKPSDM for ASN who commit violations of discipline are also guided by Law No. 5 of 2014 concerning ASN and PP No 53/2010 concerning Discipline of Civil Servants. These laws and regulations already have clear rules. The causes of discipline violations committed by Civil Servants are that Civil Servants do not understand the rules, the leadership does not act firmly, lack of inherent supervision (WASKAT), and lack of appreciation praise for subordinates.
\end{abstract}

Keywords: State Civil Apparatus, Disciplinary Violations, Sanctions

\section{PENDAHULUAN}

Undang-Undang mengenai Aparatur Sipil Negara (selanjutnya disebut ASN) berlaku sejak tahun 2014, yakni diatur dengan UU No. 5/2014 tentang Aparatur Sipil Negara (selanjutnya disebut UU ASN). Sebelum berlakunya Undang-Undang tersebut aturan mengenai Pegawai Negeri Sipil (selanjutnya disebut PNS) diatur dalam UU No. 8/1974 tentang Pokok-Pokok Kepegawaian yang selanjutnya mengalami perubahan yakni UU No. 43 Tahun 1999 tentang Perubahan Atas UU No. 8 / 1974 tentang Pokok-Pokok Kepegawaian sudah tidak sesuai dengan tuntutan nasional dan tantangan global sehingga perlu diganti dengan UU ASN. 
Seiring dengan berkembangnya zaman, ada sejumlah permasalahan yang dihadapi oleh birokrasi Indonesia berkenaan dengan Sumber Daya Manusia (SDM). SDM yang dimaksudkan adalah PNS yang ditempatkan dan bekerja di lingkungan birokrasi untuk menjalankan tugas pokok dan fungsi sebagaimana telah ditetapkan. Permasalahan tersebut antara lain besarnya jumlah PNS dan tingkat pertumbuhan yang tinggi dari tahun ke tahun, rendahnya kualitas dan ketidaksesuaian kompetensi yang dimiliki, kesalahan penempatan dan ketidakjelasan jalur karier yang dapat ditempuh (Sulistiyani, 2014).

Salah satu indikasi rendahnya kualitas PNS tersebut adalah karena tidak bisa dipungkiri masih ada oknum-oknum PNS yang melakukan pelanggaran disiplin PNS misalnya dengan melakukan tindakan yang menyimpang dari aturan yang tertulis. Untuk menghindari terulangnya hal tersebut maka diperlukan adanya sanksi-sanksi bagi Pegawai PNS yang melakukan pelanggaran (Moonti \& Polidu, 2010; Rahman, 2016; Yusuf, 2015). Disamping adanya sanksi diperlukan juga kesadaran dari diri sendiri untuk dapat menjalankan tugasnya secara profesional. Hingga saat ini masih banyak ASN yang melakukan pelanggaran disiplin. Oleh karena itulah pemerintah membuat peraturan disiplin PNS yang melakukan pelanggaran agar tidak diulang di kemudian hari yakni PP 53 / 2010 tentang Disiplin PNS.

Berdasarkan pemaparan latar belakang tersebut penulis mendesain penelitian ini dengan tujuan mengungkap bagaimana pengaturan disiplin ASN pada Pemerintah Kota Denpasar berdasarkan UU No.5 /2014 tentang ASN dan PP 53 / 2010 Tentang Disiplin PNS, dan bagaimana penegakan sanksi hukum bagi ASN yang melakukan pelanggaran disiplin di lingkungan Pemerintah Kota Denpasar.

\section{METODE PENELITIAN}

Penelitian ini didesain dengan menggunakan pendekatan empiris. Pendekatan ini digunakan karena penelitian ini mengkaji kenyataan-kenyataan yang ada dalam masyarakat atau sebuah kelompok. Data penelitian ini diperoleh melalui wawancara langsung serta pencarian data di Badan Kepegawaian dan Pengembangan Sumber Daya Manusia Kota Denspasa yang disebut BKPSDM. Data-data yang sudah terkumpul dianalisis dengan menggunakan bahan-bahan hukum yang berkaitan dengan permasalahan. Selanjutnya hasil analisis data disajikan secara informal dalam bentuk deskripsi.

\section{HASIL PENELITIAN DAN PEMBAHASAN}

Pengaturan Disiplin ASN pada Pemerintahan Kota Denpasar Berdasarkan UU No. 5 Tahun 2014 Tentang ASN dan PP 53 Tahun 2020 Tentang Disiplin PNS

ASN merupakan Pegawai Negeri Sipil dan Pegawai Pemerintah dengan Perjanjian Kerja (PPPK) yang bekerja dalam instansi pemerintah yang diangkat oleh pejabat pembina kepegawaian dan diserahi tugas dalam suatu jabatan pemerintahan atau tugas negara dan digaji berdasarkan peraturan perundang-undangan (Azis \& Jufri, 2015). Pasal 6 UU No.5 / 2014 tentang Aparatur Sipil Negara mengatur bahwa Aparatur Sipil Negara terdiri dari Pegawai Negeri Sipil (PNS) dan Pegawai dengan perjanjian kerja (PPPK).

UU ASN membedakan ASN menjadi 2 yakni PNS dan PPPK. Perbedaannya ialah jangka waktu kerja, dimana PNS diangkat secara tetap sedangkan PPPK mempunyai jangka waktu tertentu. Beban tugas yang diberikan bagi PNS yakni melaksanakan jabatan pemerintahan sedangan PPPK berdasarkan dengan instruksi dari PNS. Dalam bukunya Hartini dan Sudrajat yang berjudul Hukum Kepegawaian Di Indonesia dalam hal penerapan sanksi disiplin, Pegawai Pemerintah dengan Perjanjian Kerja (PPPK) berada dalam ranah hukum kepegawaian sedangkan jika dilihat dari hukum perjanjian kontrak pendek maka Pegawai Pemerintah dengan Perjanjian Kerja (PPPK) berada dalam ranah hukum ketenagakerjaan (Hartini \& Sudrajat, 2017).

Berdasarkan wawancara yang penulis lakukan dengan Ibu I Gusti Agung Tri Widiasari,S.H., selaku Kasubid Disiplin dan Penghargaan BKPSDM Kota Denpasar dan Ibu Ida Ayu Mas Suryaningsih, selaku pelaksana, pada tanggal 20 Januari 2020 pukul 09.00 WITA, diketahui bahwa BKPSDM hanya menangani kasus pelanggaran disiplin yang dilakukan oleh Pegawai Negeri Sipil (PNS) saja.

PP 53/2010 (Pasal 1 angka 1) mengatur bahwa disiplin PNS yakni mentaati kewajiban sebagaimana dalam Pasal 3 PP 53/2010:

1. "Mengucapkan sumpah/janji Pegawai Negeri Sipil.

2. Mengucapkan sumpah/janji jabatan. 
3. Setia dan taat sepenuhnya kepada Pancasila, UUD Negara Republik Indonesia Tahun 1945, Negara Kesatuan Republik Indonesia, dan Pemerintah; hal ini bermaksud bahwa setiap Aparatur Sipil Negara disamping taat dan berkewajiban melaksanakan Undang-Undang Dasar Negara Republik Indonesia Tahun 1945, kebijakan negara dan Pemerintah serta tidak mempermasalahkan dan/atau menentang Pancasila, dan Undang-Undang Dasar Negara Republik Indonesia 1945.

4. Menaati segala ketentuan per-UU.

5. Melaksanakan tugas kedinasan.

6. Menjunjung tinggi kehormatan negara, Pemerintah, dan martabat Pegawai Negeri Sipil.

7. Memprioritaskan kepentingan negara.

8. Menjaga rahasia jabatan sebagaimana mestinya

9. Jujur, tertib, cermat, dan bersemangat dalam bekerja.

10. Jika ada hal yang membahayakan dan merugikan negara, laporkan kepada atasan

11. Masuk dan menaati jam kerja.

12. Target kerja tercapai.

13. Menjaga dan memakai barang negara dengan baik.

14. Memberi pelayanan yang baik.

15. Mengarahkan bawahan dalam menjalankan tugas;

16. Memberikan kesempatan bawahan mengembangkan karir.

17. Taat akan aturan dinas."

dan menjauhi larangan sebagaimana dalam Pasal 4 PP 53 / 2010, yakni:

1. "Menyalahgunakan wewenang.

2. Menjadi perantara untuk mendapatkan keuntungan pribadi dan/atau orang lain dengan menggunakan kewenangan orang lain.

3. Tanpa izin Pemerintah menjadi pegawai atau bekerja untuk negara lain dan/atau lembaga atau organisasi internasional.

4. Bekerja pada perusahaan asing, konsultan asing, atau lembaga swadaya masyarakat asing.

5. Memiliki, menjual, membeli, menggadaikan, menyewakan, atau meminjamkan barang-barang baik bergerak atau tidak bergerak, dokumen atau surat berharga milik negara secara tidak sah.

6. Melakukan kegiatan bersama dengan atasan, teman sejawat, bawahan,atau orang lain di dalam maupun di luar lingkungan kerjanya dengan tujuan untuk keuntungan pribadi, golongan, atau pihak lain yang secara langsung atau tidak langsung merugikan negara.

7. Memberi atau menyanggupi akan memberi sesuatu kepada siapapun baik secara langsung atau tidak langsung dan dengan dalih apapun untuk diangkat dalam jabatan.

8. Menerima hadiah atau suatu pemberian apa saja dari siapapun juga yang berhubungan dengan jabatan dan/atau pekerjaannya.

9. Bertindak sewenang-wenang terhadap bawahannya.

10. Melakukan suatu tindakan atau tidak melakukan suatu tindakan yang dapat menghalangi atau mempersulit salah satu pihak yang dilayani sehingga mengakibatkan kerugian bagi yang dilayani.

11. Menghalangi berjalannya tugas kedinasan.

12. Memberikan dukungan kepada calon Presiden/Wakil Presiden, Dewan Perwakilan Rakyat, Dewan Perwakilan Daerah, atau Dewan Perwakilan Rakyat Daerah dengan cara :

a) Ikut serta sebagai pelaksana kampanye;

b) Menjadi peserta kampanye dengan menggunakan atribut partai atau atribut Pegawai Negeri Sipil;

c) Sebagai peserta kampanye dengan mengerahkan Pegawai Negeri Sipil lain; dan/atau

d) Sebagai peserta kampanye dengan menggunakan fasilitas negara.

13. Memberikan dukungan dengan calon Presiden/Wakil Presiden dengan cara :

a) Membuat keputusan dan/atau tindakan yang menguntungkan atau merugikan salah satu pasangan calon selama masa kampanye; dan/atau

b) Mengadakan kegiatan yang mengarah kepada keberpihakan terhadap pasangan calon yang menjadi peserta Pemilu sebelum, selama, dan sesudah masa kampanye meliputi pertemuan, ajakan,himbauan,seruan, atau pemberian barang kepada Pegawai Negeri Sipil dalam lingkungan unit kerjanya, anggota keluarga, dan masyarakat. 
14. Memberikan dukungan kepada calon anggota Dewan Perwakilan Daerah atau calon Kepala Daerah/Wakil Kepala Daerah dengan cara memberikan surat dukungan foto kopi Kartu Tanda Penduduk atau Surat Keterangan Tanda Penduduk sesuai peraturan perundang-undangan.

15. Memberikan dukungan kepada calon Kepala Daerah/Wakil Kepala Daerah, dengan cara :

a) Terlibat dalam kegiatan kampanye untuk mendukung calon Kepala Daerah/Wakil Kepala Daerah;

b) Menggunakan fasilitas yang terkait dengan jabatan dalam kegiatan kampanye;

c) Membuat keputusan dan/atau tindakan yang menguntungkan atau merugikan salah satu pasangan calon selama masa kampanye; dan/atau

d) Mengadakan kegiatan yang mengarah kepada keberpihakan terhadap pasangan calon yang menjadi peserta Pemilu sebelum, selama, dan sesudah masa kampanye meliputi pertemuan, ajakan, himbauan, seruan atau pemberian barang kepada Pegawai Negeri Sipil dalam lingkungan unit kerjanya, anggota keluarga, dan masyarakat."

Selain itu, PNS menjalankan kode etik dengan baik sebagaimana dalam Pasal 5 ayat (2) UU ASN. Ibu I Gusti Agung Tri Widiasari, SH selaku Kasubid Disiplin dan Penghargaan BKPSDM Kota Denpasar dan Ibu Ida Ayu Mas Suryaningsih selaku Pelaksana mengatakan bahwa mengenai kedisiplinan ASN berpedoman pada UU ASN dan PP 53 tahun 2020. Dari hal itu diketahui bahwa mengenai kedisiplinan ASN sudah memiliki aturan hukum yang jelas dan pada prakteknya di BKPSDM Kota Denpasar juga sudah berpedoman pada aturan yang ada.

\section{Penegakan Sanksi Hukum Bagi ASN Yang Melakukan Pelanggaran Disiplin Di Lingkungan Pemerintah Kota Denpasar}

\subsection{Jenis-Jenis Pelanggaran Disiplin Aparatur Sipil Negara}

Ibu I Gusti Agung Tri Widiasari,SH dan Ibu Ida Ayu Mas Suryaningsih mengatakan pelanggaran disiplin ASN yang sering terjadi di kota Denpasar yakni :

1. Tidak mentaati peraturan Per-UU

ASN tidak mentaati peraturan per-UU disebabkan karena ASN tersebut tidak memahami mengenai peraturan per-UU yang ada. Untuk mewujudkan Pegawai ASN yang handal, professional dan bermoral sebagai penyelenggara pemerintahan yang menerapkan prinsipprinsip kepemerintahan yang baik maka Pegawai ASN dituntut untuk memahami dan mentaati peraturan per-UU.

2. Tidak melaksanakan tugas kedinasan

Pemberian tugas kedinasan kepada ASN pada dasarnya merupakan kepercayaan dari atasan yang berwenang dengan harapan bahwa tugas itu akan dilaksanakan sebaik-baiknya. Oleh karenanya setiap Pegawai ASN wajib melaksanakan tugas kedinasan yang dipercayakan kepadanya dengan penuh pengabdian kesadaran dedikasi dan tanggung jawab.

3. Melanggar kewajiban masuk kerja dan ketentuan jam kerja

Yang dimaksud dengan kewajiban masuk kerja adalah setiap PNS wajib datang, melaksanakan tugas, dan pulang sesuai ketentuan jam kerja yang berlaku serta tidak berada ditempat umum bukan karena dinas. Jumlah ketidakhadiran kerja dihitung secara kumulatif sampai dengan akhir tahun berjalan, maksudnya pelanggaran yang dilakukan dihitung mulai bulan Januari - Desember pada tahun yang bersangkutan. Ketentuan jam kerja PNS selama 1 minggu berjumlah 37.5 jam, dan operasionalisasinya dapat disesuaikan dengan kebutuhan dan kondisi kerja dilingkungan unit kerja masing- masing. Keterlambatan jam masuk kerja dan/atau pulang lebih awal dihitung secara kumulatif dan dikonversi 7.5 jam sama dengan 1 (satu) hari tidak masuk kerja.

4. Tidak mencapai target kinerja yang ditetapkan

Target kinerja yang ditetapkan adalah adalah target yang akan dicapai oleh Pegawai ASN yang disusun dan disepakati bersama antara pegawai dengan atasan.

Faktor-faktor yang menyebabkan Aparatur Negara melakukan pelanggaran disiplin yakni kurang memahami peraturan perundang-undangan, tingkat kesadaran disiplin ASN yang rendah, kualitas SDM yang rendah, atasan yang tidak tegas, adanya budaya ewuh pakewuh (rasa sungkan dari atasan untuk menjatuhkan hukuman kepada bawahannya), kurangnya komitmen dalam level kepemimpinan, dan setiap pelanggaran disiplin hanya ditindaklanjuti dengan pembinaan dan teguran.

Berdasarkan hasil wawancara tersebut diketahui bahwa faktor2 utama yang menyebabkan ASN melakukan pelanggaran disiplin yaitu tidak adanya kesadaran dari dalam diri ASN untuk menjadi 
Aparatur Negara yang disiplin dan juga pemahaman yang kurang terhadap aturan-aturan yang telah ada. Padahal aturan-aturan yang telah sudah jelas dan tegas mengatur mengenai larangan dan kewajiban yang harus ditaati oleh PNS. Apabila ASN memahami aturan tersebut maka ASN tidak akan melanggar ketentuan yang ada sebagaimana tercantum dalam UU terutama mengenai kewajiban dan larangan yang harus ditaati. Selain itu faktor utama yang menjadi penyebab adanya pelanggaran Disiplin ASN adalah atasan yang tidak bersikap tegas terhadap bawahannya.

\subsection{Penegakan Disiplin Aparatur Sipil Negara di lingkungan pemerintah Kota Denpasar}

Penegakan disiplin Aparatur Sipil Negara merupakan langkah untuk mewujudkan tercapainya peningkatan kinerja Aparatur Negara dalam memenuhi pelayanan publik. Penegakkan disiplin dilihat sebagai kegiatan untuk mewujudkan keinginan-keinginan hukum menjadi kenyataan, yang berarti usaha untuk mewujudkan nilai-nilai dasar dalam hukum, seperti keadilan, kepastian hukum, dan kemanfaatan (Rahardjo, 2006).

Ibu I Gusti Agung Tri Widiasari,SH dan Ibu Ida Ayu Mas Suryaningsih mengatakan bahwa BKPSDM Kota Denpasar mempunyai Tim Kepembinaan ASN yang salah satu fokusnya adalah untuk membina ASN. Tim Kepembinaan ASN tersebut terdiri dari Inspektorat dan Bagian Hukum. Tim Kepembinaan ini turun ke lapangan untuk memberikan informasi kepegawaian dan disiplin kepada ASN di masing-masing SKPD (Satuan Kerja Perangkat Daerah) agar mengetahui bagaimana disiplin seorang ASN beserta dengan kode etiknya karena banyak ASN yang tidak memahami disiplin ASN itu seperti apa sehingga dengan adanya sosialisasi dari Tim Kepembinaan ini diharapkan tidak ada lagi ASN yang melanggar. Selain itu upaya BKPSDM untuk menegakkan disiplin ASN yakni (Badan Kepegawaian dan Pengembangan Sumber Daya Manusia Kota Denpasar, 2017):

1. Melakukan absen sidik jari

Absen sidik jari tersebut merupakan langkah yang efektif untuk mengatur dan memantau kedisiplinan para pegawai.

2. Melakukan sidak GDN (Gerakan Disiplin Nasional).

Sidak Gerakan Disiplin Nasional ini dilakukan dengan turun langsung ke perangkat daerah untuk mengetahui dan menilai bagaimana situasi dan perilaku ASN dan perangkat daerah itu sendiri seperti melihat apakah Aparatur Sipil Negara sudah datang tepat waktu dan sudah memakai identitas dengan lengkap. Sidak ini tidaklah bertujuan untuk mencari kesalahan ASN melainkan untuk menilai ASN. Dalam sidak Gerakan Disiplin Nasional ini terdapat 3 (tiga) budaya yakni budaya tertib (budaya tertib tersebut melihat apakah ASN tertib dan mematuhi aturan-aturan di tempat umum), budaya bersih (Kebersihan perangkat daerah dan ASN), dan budaya kerja (ASN mentaati ketentuan jam kerja).

3. Pengawasan Melekat (WASKAT)

WASKAT ini merupakan serangkaian kegiatan pengendalian yang secara rutin dilakukan oleh atasan langsung terhadap.

Berdasarkan hasil wawancara tersebut diketahui bahwa Badan kepegawaian dan Pengembangan Sumber Daya Manusia hanya menangani jenis pelanggaran displin berat yang dilakukan oleh Aparatur Sipil Negara dan hukuman tersebut ditangani hanya apabila ada laporan dari perangkat daerah. Dalam penegakkan Disiplin Aparatur Sipil Negara, Badan Kepegawaian dan Pengembangan Sumber Daya Manusia mempunyai Tim Kepembinaan Aparatur Sipil Negara yang akan turun langsung ke lapangan untuk memberikan sosialisasi kepada Aparatur Sipil Negara dan juga Tim Pemeriksa yang akan menangani apabila terdapat suatu kasus berat. Dengan adanya sosialiasi tersebut diharapkan Aparatur Sipil Negara dapat memahami dan menerapkan kedisiplinan. Selain itu, disamping melakukan absen sidik jari dan Gerakan Disiplin Nasional (GDN), faktor utama yang dapat meningkatkan kedisiplinan Aparatur Sipil Negara yakni lingkungan kerja, seperti diberikan apresiasi, pujian, perhatian dan kasih sayang dari atasan.

Ibu I Gusti Agung Tri Widiasari,SH dan Ibu Ida Ayu Mas Suryaningsih juga mengatakan bagi ASN yang kinerjanya baik telah mematuhi aturan, dan tidak melanggar disiplin akan diberikan penghargaan (reward) atas prestasi kerja yang telah dicapainya. Menurut Moh As'ud, prestasi kerja merupakan kesuksesan seseorang dalam melaksanakan pekerjaannya (Anggara, 2016). Penghargaan (reward) tersebut tidak hanya berupa uang tetapi juga bisa berupa apresiasi dan pujian dari atasan, kasih sayang dan perhatian dari atasan pengembangan kompetensi, rekomendasi untuk mengikuti 
diklat-diklat, dan lain-lain. Dengan adanya penghargaan (reward), maka diharapkan ASN tidak ada alasan lagi untuk melakukan pelanggaran disiplin.

\subsection{Sanksi Hukum bagi ASN yang Melakukan Pelanggaran Disiplin}

Berdasarkan hasil wawancara yang dilakukan bersama Ibu I Gusti Agung Tri Widiasari, S.H. dan Ibu Ida Ayu Mas Suryaningsih dapat diketahui bahwa penjatuhan sanksi hukum terhadap ASN yang melakukan pelanggaran disiplin di BKPSDM Kota Denpasar tetap berpedoman pada Pasal 86 ayat (3) UU ASN yakni dijatuhkan hukuman disiplin yang terdiri dari hukuman disiplin ringan, sedang, dan berat. Hukuman disiplin ringan berupa teguran lisan, tertulis, dan pernyataan tidak puas secara tertulis. Hukuman disiplin sedang berupa penundaan gaji berkala, penurunan gaji sebesar satu kali kenaikan gaji berkala, dan penundaan kenaikan pangkat, dan hukuman disiplin berat berupa penurunan pangkat pada pangkat setingkat lebih rendah, pembebasan dari jabatan, pemberhentian dengan hormat sebagai ASN atas permintaan sendiri, dan pemberhentian tidak dengan hormat sebagai ASN. Adapun mekanisme penjatuhan sanksi juga sudah berpedoman pada PP 53 tahun 2020 yakni tahap pemanggilan, tahap pemeriksaan, tahap penjatuhan hukuman, dan tahap penyampaian keputusan hukuman disiplin.

a) Dalam tahap pemanggilan, ASN yang melakukan pelanggaran disiplin dipanggil oleh atasan langsung paling lambat 7 (tujuh) hari kerja sebelum tanggal pemeriksaan. Apabila yang bersangkutan tidak hadir, maka dilakukan pemanggilan kedua paling lambat 7 (tujuh) hari kerja sejak tanggal pemanggilan pertama. Jika yang bersangkutan tetap tidak hadir, maka pejabat yang berwenang menjatuhkan hukuman disiplin berdasarkan alat bukti dan keterang an yang ada tanpa dilakukan pemeriksaan.

b) Dalam tahap pemeriksaan, pemeriksaan dilakukan secara lisan atau tertulis. Pemeriksaan dilakukan secara tertutup.Hasil pemeriksaan dituangkan dalam BAP.. Syarat yang diperlukan dalam melakukan pemeriksaan yaitu teliti dan objektif (Soekarno, 1983).

c) Dalam tahap penjatuhan hukuman, ASN yang terbukti melakukan pelanggaran disiplin, dijatuhi hukuman disiplin yang setimpal dengan pelanggaran yang dilakukan. Apabila tidak terdapat pejabat yang berwewenang menghukum, maka kewenangan menjatuhkan hukuman disiplin menjadi kewenangan pejabat yang lebihtinggi. ASN yang ternyata melakukan beberapa pelanggaran disiplin hanya dapat dijatuhi 1 (satu) hukuman disiplin yang terberat. ASN yang pernah dijatuhi hukuman disiplin, kemudian melakukan pelanggaran disiplin yang sifatnya sama, kepadanya dijatuhi hukuman disiplin yang lebih berat dari hukuman disiplin yang terakhir, kecuali ketentuan hukuman masuk menaati jam kerja.

d) Dalam tahap penyampaian keputusan hukuman disiplin, setiap penjatuhan hukuman disiplin ditetapkan dengan keputusan pejabat yang berwenang menghukum. Keputusan disampaikan secara tertutup oleh pejabat yang berwenang menghukum atau pejabat lain yang ditunjuk kepada PNS yang bersangkutan serta tembusananya disampaikan kepada pejabat instansi terkait. Penyampaian keputusan hukuman disiplin dilakukan paling lambat 14 hari kerja sejak keputusan ditetapkan. Dalam hal PNS yang dijatuhi hukuman tidak hadir pada saat penyampaian keputusan hukum disiplin, keputusan dikirim kepada yang bersangkutan (Badan Kepegawaian dan Pengembangan Sumber Daya Manusia Kota Denpasar, 2017).

\section{Jumlah Kasus Pelanggaran Disiplin ASN di Pemerintahan Kota Denpasar dari Tahun 2018 sampai dengan 2019}

\begin{tabular}{llcc}
\hline \multirow{2}{*}{ No } & \multirow{2}{*}{ Jenis Pelanggaran Disiplin } & \multicolumn{2}{c}{ Tahun Dan Jumlah Kasus } \\
\cline { 3 - 4 } 1 & Melanggar ketentuan jam kerja & $\mathbf{2 0 1 8}$ & $\mathbf{2 0 1 9}$ \\
\hline 2 & Tidak melaksanakan tugas kedinasan & 4 & 2 \\
\hline 3 & Narkoba & 2 & 2 \\
\hline 4 & Pungutan Liar & - & - \\
\hline 5 & Penyalahgunaan wewenang & - & 2 \\
\hline
\end{tabular}




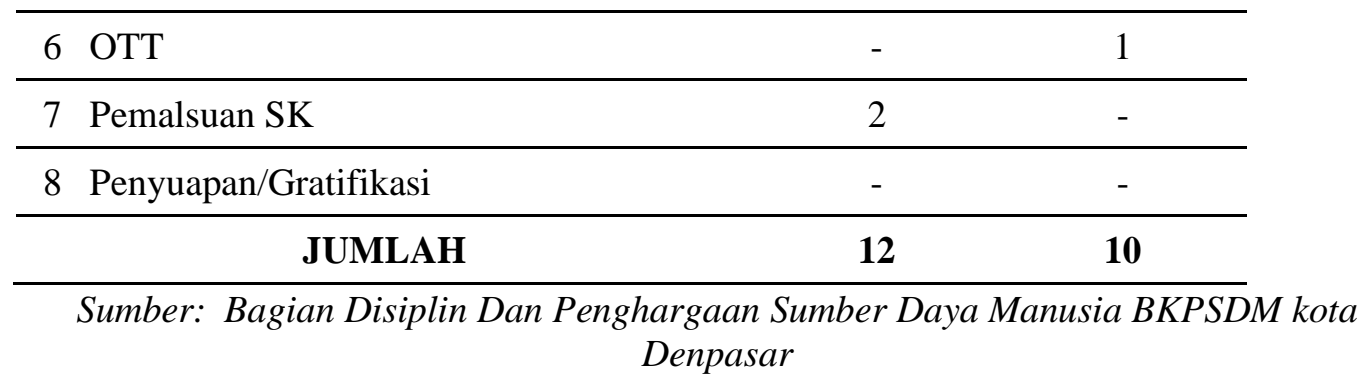

Berdasarkan data tersebut diketahui bahwa pelanggaran disiplin yang paling sering terjadi di tahun 2018 adalah melangar ketentuan jam kerja dan tidak melaksanakan tugas kedinasan, sedangkan pelanggaran disiplin yang paling sering terjadi di tahun 2019 adalah penyalahgunaan wewenang. Namun, jumlah pelanggaran tersebut mengalami penurunan yang signifikan setiap tahunnya yakni jumlah total dari pelanggaran disiplin ASN di tahun 2018 berjumlah 12, dan menurun menjadi 10 di tahun 2019. Hal tersebut menunjukkan bahwa upaya BKPSDM Kota Denpasar kondusif untuk menangani ASNF yang melakukan pelanggaran disiplin.

\section{SIMPULAN DAN SARAN}

1. Simpulan

Berdasarkan hasil penelitian ini, ada beberapa simpulan yang dapat dibuat, yaitu: pertama, Kedisiplinan ASN di BKPSDM Kota Denpasar diatur dan berpedoman pada UU ASN dan PP 53 / 2010 tentang Disiplin PNS dimana ASN dikatakan disiplin apabila mematuhi kode etik sebagaimana diatur dalam Pasal 5 ayat (2) UU ASN. ASN yang disiplin juga taat akan kewajiban- kewajiban dalam Pasal 3 PP 53 / 2010 tentang Disiplin PNS dan menjauhi larangan- larangan sebagaimana tercantum dalam Pasal 4 Peraturan Pemerintah Nomor 53/2010 tentang Disiplin PNS. Kedua, Penegakan sanksi hukum BKPSDM Kota Denpasar bagi ASN yang melakukan pelanggaran disiplin di lingkungan pemerintah Kota Denpasar berpedoman pada UU ASN dan PP 53/2010 tentang Disiplin PNS. Aturan tersebut sudah jelas dan tegas. Namun, penyebab masih terjadinya pelanggaran disiplin yang dilakukan oleh ASN yaitu ASN tidak memahami peraturan perundang-undangan dan juga pemimpin/atasan yang tidak bersikap tegas terhadap bawahannya, kurangnya WASKAT dan kurangnya apresiasi/pujian yang diberikan oleh atasan terhadap bawahannya.

\section{Saran}

Saran yang dapat sampaikan berdasarkan permasalahan yang telah paparkan adalah: pertama, diharapkan bagi atasan agar dapat memberikan penghargaan (reward) kepada bawahannya, berupa apresiasi dan pujian karena dengan adanya penghargaan (reward) tersebut akan memicu ASN untuk bekerja lebih maksimal. Selain itu juga diharapkan agar atasan langsung dapat memberikan sanksi yang tegas terhadap bawahannya yang melakukan pelanggaran, kedua, agar ASN tidak melakukan pelanggaran disiplin, dan ketiga bagi Tim Kepembinaan Pegawai agar secara rutin melakukan sosialisasi kepada ASN karena dengan adanya sosialisasi diharapkan ASN dapat lebih mengerti dan memahami mengenai kedisiplinan.

\section{DAFTAR PUSTAKA}

Anggara, S. (2016). Administrasi Kepegawaian Negara. Bandung: Pustaka Setia.

Azis, \& Jufri. (2015). Implementasi Aparatur Sipil Negara dalam Bidang Kesehatan untuk Pembinaan Karir Jabatan Fungsional Epidemologi Kesehatan. Kendari: CP Press.

Badan Kepegawaian dan Pengembangan Sumber Daya Manusia Kota Denpasar. (2017). Penyusunan Buku Panduan Pengawasan Melekat (Waskat) dalam Rangka Meningkatkan Disiplin Pegawai Negeri Sipil. Denpasar: Badan Kepegawaian dan Pengembangan Sumber Daya Manusia Kota Denpasar.

Hartini, S., \& Sudrajat, T. (2017). Hukum Kepegawaian di Indonesia (II). Jakarta: Sinar Grafika.

Moonti, R. M., \& Polidu, I. (2010). Penerapan Peraturan Sanksi Disiplin Bagi Aparatur Sipil Negara

Di Lingkungan Pemerintah Daerah Badan Kepegawaian Daerah Kabupaten Gorontalo Utara. 
Gorontalo Law Review, 1(1), 1-14.

Rahardjo, S. (2006). Ilmu Hukum. Bandung: Citra Aditya Bakti.

Rahman, R. H. (2016). Analisis Pemeberian Sanksi dalam Menegakkan Disiplin Pegawai Negeri Sipil (Studi Badan Keluarga Berencana Dan Pemberdayaan Perempuan Kabupaten Pringsewu) (Universitas Lampung).

Soekarno. (1983). Himpunan Soal-Jawab Kepegawaian Negeri Sipil. Jakarta: Miswar.

Sulistiyani, A. T. (2014). Memahami Good Governance dalam Perspektif Sumber Daya Manusia. Yogyakarta: Gaya Media.

Yusuf, A. (2015). Pemberian Sanksi Pelanggaran Disiplin Aparatur Sipil Negara di Lingkungan Pemerintah Daerah Kabupaten Sigi Guna Meningkatkan Pelayanan Publik. E-Jurnal Katalogis, 3(11), 118-129.

Peraturan Pemerintah Nomor 53 Tahun 2010 tentang Disiplin Pegawai Negeri Sipil; Peraturan

Pemerintah Nomor 11 Tahun 2017 tentang Manajemen Pegawai Negeri Sipil;

Peraturan Kepala Badan Kepegawaian Negara Nomor 21 Tahun 2010 tentang Ketentuan Pelaksanaan Peraturan Pemerintah Nomor 53 Tahun 2010.

Undang-Undang Nomor 5 tahun 2014 tentang Aparatur Sipil Negara (Lembaran Negara Republik Indonesia Tahun 2014 Nomor 6, Tambahan Lembaran Negara Republik Indonesia Nomor 5494).

Undang-Undang Negara Republik Indonesia Tahun 1945 (Lembaran Negara Republik Indonesia Tahun 1959 Nomor 75) 